\title{
Inovasi SIEC-ITS dalam Implementasi Teknologi Informasi dan [Tele]Komunikasi Mendukung Framework Smart-city yang Berkelanjutan
}

\author{
Endroyono1; Achmad Affandi2; Eko Setijadi3; Gatot Kusrahardjo4; Djoko Suprajitno5 \\ 1,2,3,4,5 Dosen Jurusan Teknik Elektro FTI ITS \\ endroyono@ee.its.ac.id
}

\begin{abstract}
Abstrak
"Smart-city \& Intelligent Approach" merupakan terminologi yang membuat kota-kota di Indonesia tertantang untuk memanfaatkan TIK di semua aktifitas. Namun demikian, ada data, bahwa lebih dari $47 \%$ proyek TIK dinyatakan kurang berhasil. Hal ini mendorong SIEC-ITS melakukan pengembangan dan inovasi, yang tidak saja yang bersifat makro (kebijakan dan frame work), tapi juga aplikasi nyata di lapangan, berupa hardware dan software. Master-Plan Intelligent Transportation Surabaya (ITS) adalah contoh produk makro yang dijadikan rujukan hingga saat ini. Master Plan ini melahirkan inovasi aplikasi S-ITS, sebuah sistem pengaturan lalu-lintas adaptif yang seluruh interfacenya dikembangkan oleh anak-anak bangsa. SIEC-ITS juga sedang menguji coba sistem manajemen armada dan sistem manajemen revenu untuk angkutan massal cepat (AMC) Surabaya. Untuk melengkapi itu, SIEC-ITS melakukan integrasi sistem e-Dishub, sebagai bagian dari konsep "Smart-Mobility". Dengan interintegrasi ini, maka data dan informasi dari aplikasi e-Lalin, eTransport, e-Perijinan, e-Pengujian, e-Sekretariat, e-Terminal, termasuk e-Parkir akan berada dalam satu platform terpadu, sehingga manajemen lalu-lintas, penataan transportasi dan pengendalian sarana-prasarana dapat dilakukan secara tepat, efektif dan efisien.
\end{abstract}

Kata kunci: smart-city, TIK, S-ITS, e-Dishub, SIEC-ITS

\section{PENDAHULUAN}

Ketika makalah ini ditulis, walikota Surabaya sedang berada di kota Dublin Irlandia dalam rangka menerima penghargaan Smart-city dunia dan mempersiapkan Surabaya dalam rangka Forum Smart-Nation, sebuah upaya meningkatkan lingkup pengembangan dari Smart-city menjadi Smart-Nation. Keberhasilan ini, oleh Walikota Surabaya selalu dikatakan sebagai keberhasilan masyarakat Surabaya, pemuda-pemuda Surabaya dan perguruan tinggi; khususnya Perguruan Tinggi yang mempunyai bidang Teknologi Informatika dan Komunikasi, seperti ITS dan beberapa perguruan tinggi lain. Artinya, penerintah kota Surabaya telah berhasil menggabungkan potensi akademisi, masyarakat industri, dengan pemerintah $(\mathrm{ABG})$.

Ketertarikan Kota Surabaya bekerja sama dengan perguruan tinggi mendorong ITS mengoptimalkan fungsi-fungsi jurusan/departemen, laboratorium dan SDM ITS untuk secara penuh membantu kota-kota dan juga di skala nasional dalam bidang smart-city dan penyelesaian masalah secara cerdas (intelligent solution). Itulah sebabnya, sangat tepat bila seminar CINIA ke 2 ini mengambil tema "Boosting Nation's Competitiveness through Research and Innovation", yang artinya meningkatkan daya saing bangsa melalui penelitian (research) dan inovasi (innovation). Hasil-hasil penelitian yang tidak dilanjutkan sebagai produk inovasi tidak akan mempunyai efek pendorong bagi pembangunan dan kekuatan kompetitif bangsa. Dari sisi kebijakan memang pemerintah telah mulai mencanangkan skenari penelitian yang berujung pada penerapan konsep TRL (Technological Readyness Level), di mana setiap penelitian diberi label mulai TRL 1-6 yang berisi penelitian ilmu dasar dan pengembangan Iptek, serta TRL 7-9 yang telah masuk ke area Teknologi Terapan.

Mengacu pada kompleksitas permasalahan smart-city yang meliputi berbagai aspek dari problem mulai pola-fikir dan framework, hingga pelaksanaan pilar smart-city (seperti smart governance, smart mobility, smart environment, smart living, smart people, dan smart economy), maka setiap elemen di ITS berkewajiban mengembangkan berbagai inovasi sesuai dengan ilmu dan keahlian masing-masing. Untuk itulah Jurusan Teknik Elektro, sebagai jurusan yang menjadi core dari ICT/TIK membentuk research group yang diberi nama SIEC-ITS (smart-city and Intelligent Excellent Center ITS). Group ini telah berhasil memberikan sumbangsih berupa berbagai sistem, teknologi terapan dan pemanfaatan ilmu pengetahuan. SIECT telah memberdayakan tidak saja peneliti dari Teknik Elektro, Teknik Multimedia dan Jaringan, dan Teknik Biomedik, tetapi juga dengan sipil transportasi dan jurusan-jurusan dan kepakaran lain. Aktifitas SIEC-ITS inilah 
yang akan menjadi inti dari makalah ini. Pembahasan akan dimulai dengan konsep Smart-city yang menjadi lahan dari inovasi SIEC-ITS. Bahasan tersebut disusul dengan deskripsi aktifitas penelitian dan pengabdian SIEC-ITS, serta ditutup dengan deskripsi berbagai inovasi SIEC-ITS untuk mendukung smart-city.

\section{KONSEP SMART CITY BERBASIS TIK/ICT}

Smart-city telah menjadi jargon nasional yang mempunyai efek sangat besar di era ini, bagi kota-kota di Indonesia jargon ini menjadi pendorong, tetapi juga sekaligus menjadi sumber permasalahan, khususnya bila dikaitkan dengan aspek Model bisnis kota (operasional dan layanan), regulasi dan tentunya teknologi.

Prof. Dr. Ir. Suhono H. (ITB) menyampaikan, dalam kontek Model Garuda Smart-city Model, smart-city adalah kota yang mampu memanage sumber daya, termasuk sumber-daya alam; sehingga masyarakat dapat hidup dengan aman, nyaman secara berkelanjutan. Dalam kerangka ini, teknologi informasi dan komunikasi (TIK/ ICT) menjadi sarana wajib untuk membantu manajemen (kota yang semakin kompleks). Model garuda ini tergambar pada Gambar 1.(a). Dalam banyak kesempatan Endroyono (ITS) dan Team SIEC-ITS, lebih sering menggunakan model generik yang digunakan secara internasional, yaitu model snart-city dengan 6 Pilar, yaitu: (1) Smart Gouvernance, (2) Smart People, (3) Smart Living, (4) Smart Environment, (5) Smart Mobility, dan (6) Smart Economy.

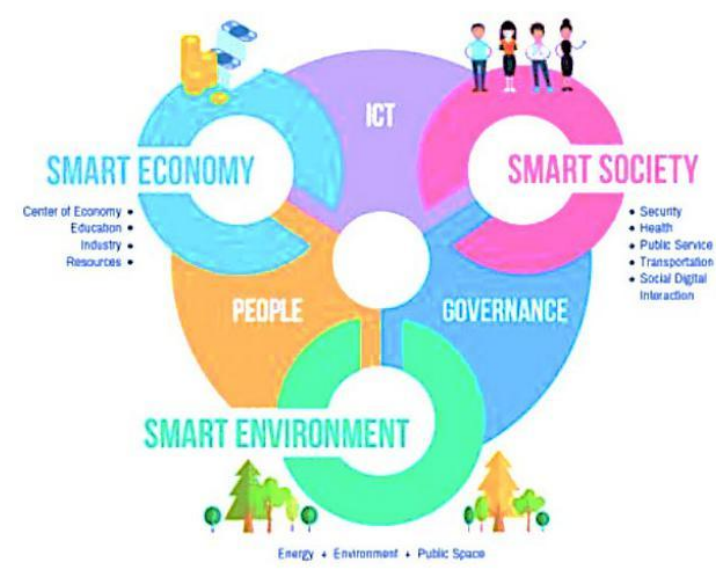

(a)

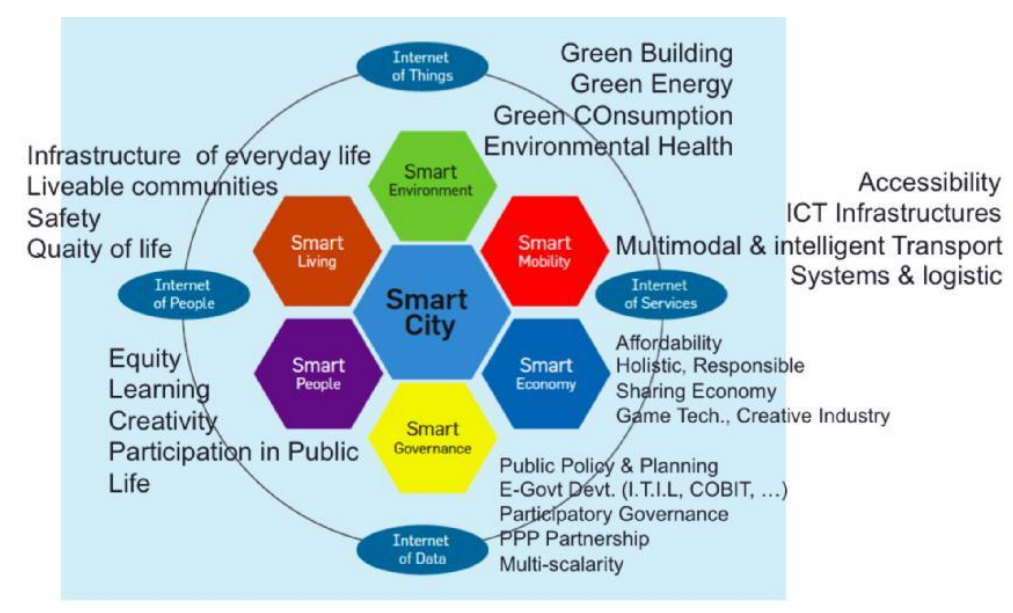

(b)

Gambar 1. (a) Model Garuda Smart-city, dan (b) Model yang digunakan oleh SIEC-ITS

Sebenarnya kedua model mempunyai elemen yang serupa, tetapi pemilihan model 1.(b) lebih dipilih berdasarkan pada kemudahan clustering, tidak saja pada tujuan (yang oleh model 1 dirangkum sebagai Smart Society, Smart Economy dan Smart Environtment), tetapi lebih pada upaya melakukan clustering dan sekaligus mensinergikan potensi yang dapat dikembangkan di setiap pilar. Dan dari sudut pandang ITS, clustering ini mempermudah pemberdayaan keahlian masingmasing kelompok riset, atau jurusan/departemen. Sebagai contoh, dengan mengambil contoh beberapa pilar kita bisa melakukan penjabaran potensi jurusan yang bisa terlibat dan dilibatkan.

Tabel 1. Relasi Pilar Smart-city, pengelola dan pengembang

\begin{tabular}{|c|c|c|c|}
\hline Pilar & Aspek & Dinas Terkait & Jurusan Pengembang \\
\hline \multirow{4}{*}{$\begin{array}{l}\text { Smart } \\
\text { Mobility }\end{array}$} & Accessibility & Dinas Kominfo & Teknik Elektro, TMJ, Informatika, Sistem Informasi, ... \\
\hline & $\begin{array}{l}\text { ICT } \\
\text { Infrastructure }\end{array}$ & $\begin{array}{l}\text { Dinas Kominfo, Dinas } \\
\text { Perhubungan, Tata-kota, ... }\end{array}$ & $\begin{array}{l}\text { Teknik Elektro, TMJ, Informatika, Sistem Informasi, ... } \\
\text { Teknik Sipil, Sipil, Tata-kota (PWK), lingkungan }\end{array}$ \\
\hline & $\begin{array}{l}\text { Multimodal \& } \\
\text { Intelligent } \\
\text { Transport }\end{array}$ & $\begin{array}{l}\text { Dinas Perhubungan, Dinas } \\
\text { Kominfo, Dinas Tata-kota, } \\
\text { Dinas Pendapatan, ... }\end{array}$ & $\begin{array}{l}\text { Teknik Mesin, Teknik Elektro, Teknik Perkapalan TMJ, } \\
\text { Informatika, Sistem Informasi, ... Teknik Fisika,Teknik } \\
\text { Sipil Transport, Sipil, Tata-kota (PWK), Teknik } \\
\text { Lingkungan }\end{array}$ \\
\hline & $\begin{array}{l}\text { System \& } \\
\text { Logistic }\end{array}$ & $\begin{array}{l}\text { Dinas Perhubungan, Dinas } \\
\text { perdagangan dan Perindustrian, } \\
\text { Dinas Pendapatan, ... }\end{array}$ & $\begin{array}{l}\text { Teknik Elektro, TMJ, Teknik Industri, Statistik, } \\
\text { Informatika, Sistem Informasi, ... Teknik Mesin, } \\
\text { Teknbik Fisika,Teknik Sipil Transport, Sipil, Tata-kota } \\
\text { (PWK), Teknik Lingkungan }\end{array}$ \\
\hline $\begin{array}{l}\text { Smart } \\
\text { Governance }\end{array}$ & $\begin{array}{l}\text { Public Policy \& } \\
\text { Planning }\end{array}$ & $\begin{array}{l}\text { Bappeko, Bina Program, Dinas } \\
\text { Kominfo, Dinas Tata-kota, ... }\end{array}$ & MMT, Sistem Informasi, Teknik Industri, Statistik, .... \\
\hline ... & $\ldots$ & $\ldots$ & \\
\hline
\end{tabular}


Dengan pendekatan tersebut, semua elemen di ITS yang tertarik pada pengembangan Smart-city akan dengan mudah bekontribusi di jalurnya masing-masing, tentunya dengan catatan bahwa semua yang dilakukan diarahkan untuk memanfaatkan teknologi ICT. Dan pada akhirnya, penerapan ICT di sebuah kota diharapkan dapat dilakukan untuk membantu model bisnis kota mulai dari memberikan layanan, mempermudah operasional kota termasuk perencanaan, dan tentunya dalam rangka pengawasan dan keterbukaan informasi publik. Dalam kerangka tersebut, maka diperlukan adanya ICT Leadership dari pemimpin kota. Dengan leadership yang baik, maka seluruh pemangku kepentingan akan mempunyai strategi yang solid dalam rangka membentuk proses yang baik dan berkesinambungan. Di sisi lain, smart-city tidak akan pernah bisa selesai tanpa adanya kerja-sama dan kolaborasi, khususnya kerjasama antara ABG (Akademisi, Bisnis/Industri dan Pemerintah). Tanpa kerja-sama yang baik, maka akan terjadi berbagai kendala yang sebenarnya bisa dihindari. Hal terakhir yang sangat penting, TIK dapat dimanfaatkan sebagai alat ukur, baik dalam mengukur kinerja maupun dalam rangka keterbukaan. Melalui sistem IT dan komunikasi yang baik, seluruh progress dapat tersampaikan dan seluruh kendala dapat terpantau melalui feedback yang kredibel.

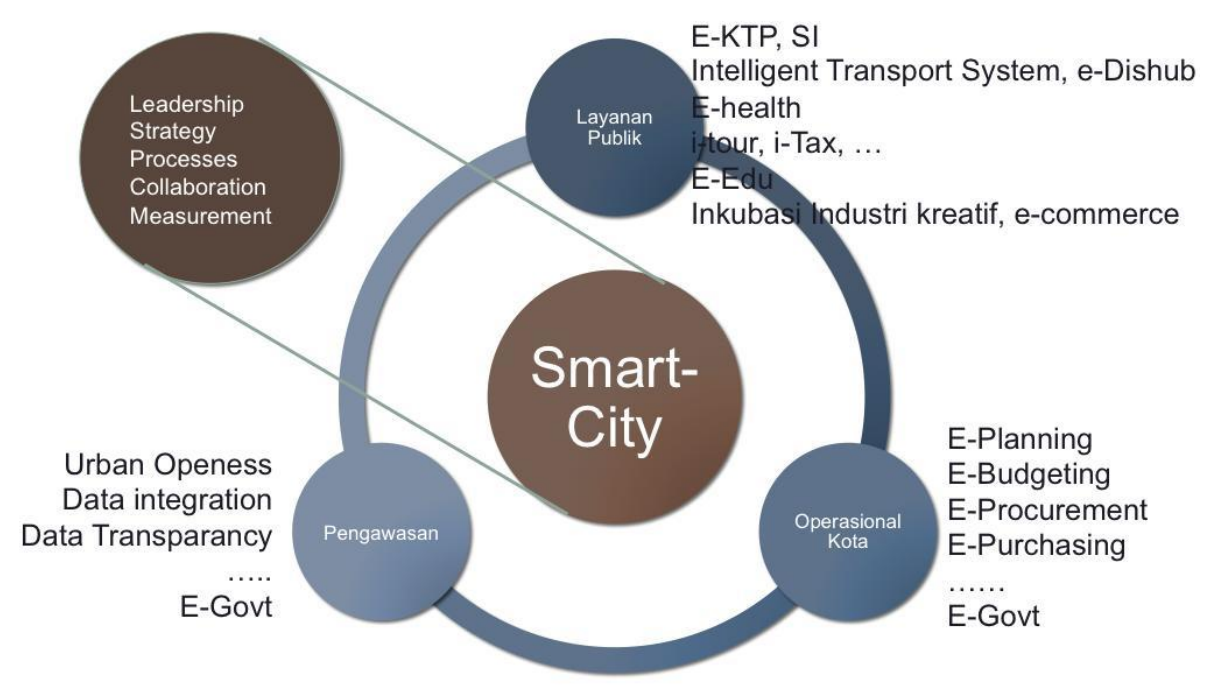

Gambar 2. Bagaimana teknologi (TIK) membantu operasional kota, layanan publik dan pengawasan

Pada akhirnya tidak salah bila sebagian besar kota berlomba untuk dapat disebut sebagai sebuah SMART-CITY. Akan tetapi harus disadari, bahwa pengembangan smart city tidak dapat dilepaskan dari adanya investasi, yaitu investasi sistem dan perangkat TIK. Selama ini, terjadi kesalahan umum menuju smart-city adalah bahwa sebagian besar stake-holder menganggap, bahwa teknologi TIK/ICT yang ditawarkan vendor atau penyedia merupakan teknologi yang secara langsung akan mampu menyelesaikan setiap permasalahan kota, termasuk yang paling kompleks. Sedangkan kunci utamanya adalah kemampuan dalam mendefinikan layanan/ model bisnis kota, pemahaman regulasi dan baru pencarian akan teknologi TIK/ ICT yang sesuai dengan kemampuan, skala dan kompleksitas di kota yang ingin menerapkannya.

Dalam kerangka tersebut, maka diperlukan upaya-upaya pencerahan, pendampingan, hingga bantuan pemilihan teknologi dan implementasinya di lapangan dengan tetap memperhatikan aspek layanan (model bisnis), regulasi dan optimalisasi pemanfaatan teknologi. Dan semuanya itu dapat berlangsung dengan baik, apabila kota mempunyai narasumber berkompeten di bidang-bidang tertentu dari pilar Smart-city untuk membantu setiap aktifitasnya. Dan inilah satu diantara peran dari perguruan tinggi, khususnya perguruan tinggi teknologi.

\section{AKTIFITAS PENELITIAN \& PENGABDIAN SIEC-ITS}

SIEC-ITS (Smart-city \& Intelligent Excellent Center ITS) adalah sebuat research group, artinya merupakan kumpulan dari para peneliti dan penggiat penerapan TIK dalam platform Smart-city dan pencarian solusi cerdas (intelligent) dari permasalahan-permasalahan di masyarakat. Team ini berisikan para peneliti dari Laboratorium Jaringan Telekomunikasi (B.301), Lab. Telekomunikasi Multimedia (B. 304), Lab. Antenna \& Propagasi (B.306), Lab. Sistem Telekomunikasi (AJ.404), Laboratorium Jaringan dan Multimedia di Jurusan TMJ, Lab. Sipil Transport dan termasuk pemanfaan Lab. Informatika saat uji coba security.

Para peneliti dari berbagai bidang ini tertarik masuk ke ranah Smart-city, karena selain telah menjadi jargon nasional dan mempunyai efek sangat besar, namun ternyata juga membingungkan pengembang TIK di tiap kota di Indonesia. Kebingungan tersebut muncul terkait dengan pertanyaan, bagaimana merealisasikan setiap pilar dari model smart-city. Sebagai contoh, penerapan Smart Mobility yang menerapan teknologi TIK di bidang transportasi dalam bentuk ITS, disadari bahwa pengaruhnya sangat vital bagi Negara berkembang, karena berhubungan dengan biaya transportasi, energi, dan kesehatan lingkungan, tetapi sulit untuk memperoleh aplikasi, platform, produk atau standard yang menjadi acuan untuk diterapkan di kota-kota di Indonesia, yang tingkat ekonominya berbeda-beda.

Untuk itulah berbagai judul penelitian diusulkan oleh para peneliti SIEC-ITS. Dalam skala makro, SIEC-ITS ingin berkontribusi dalam rangka mempersiapkan platform-platform standard dari setiap Pilar. Platform-platform standard ini diharapkan dapat menjadi salah satu rujukan penerapan smart-city nasional atau smart-nation bila memungkinkan. 
Dalam kontek penelitian teknologi mikro, para peneliti SIEC-ITS melakukan penelitian di laboratorium dalam rangka penyusunan konsep dan framework, perancangan dan pembuatan perangkat lunak aplikasi; serta perancangan dan pembuatan perangkat keras, mulai dari modul hingga sistem besar. Dengan hasil penelitian oleh SIEC-ITS ini, diharapkan ITS dan Negara ini mempunyai prototype Laboratorium yang siap disesuaikan dengan kebutuhan penerapan dan Industri, dengan minimal TRL-6, dan kemungkinan terbantu untuk pendapatkan patent dan industrialisasi penuh di TRL-9. Pada intinya SIEC-ITS ingin mempunyai kegiatan yang mewadahi aktifitas dari penelitian murni untuk penggalian ide, mengembangkan konsep dan solusi, pengembangan prototype, hingga adopsi teknologi dalam rangka memberikan rekomendasi, integrasi sistem, penyusunan draft kebijakan, hingga pelatihan dan workshop diseminasi. Karena merupakan bagian dari ITS, maka setiap saat team melakukan performance management dalam rangka evaluasi kegiatan, identifikasi kinerja dan mencari peluang-peluang perbaikan. Salah satu aktifititas yang tidak kalah pentingnya dalam aktifitas ini adalah perlunya technology tracking, di mana para peneliti harus tanggap terhadap teknologi-teknologi terbaru, sehingga mampu menemukan teknologi yang menjamin tercapainya tujuan dan kinerja dari semua fungsi yang dirancang dan mendukung semua kegiatan yang digunakan untuk pengambilan keputusan.

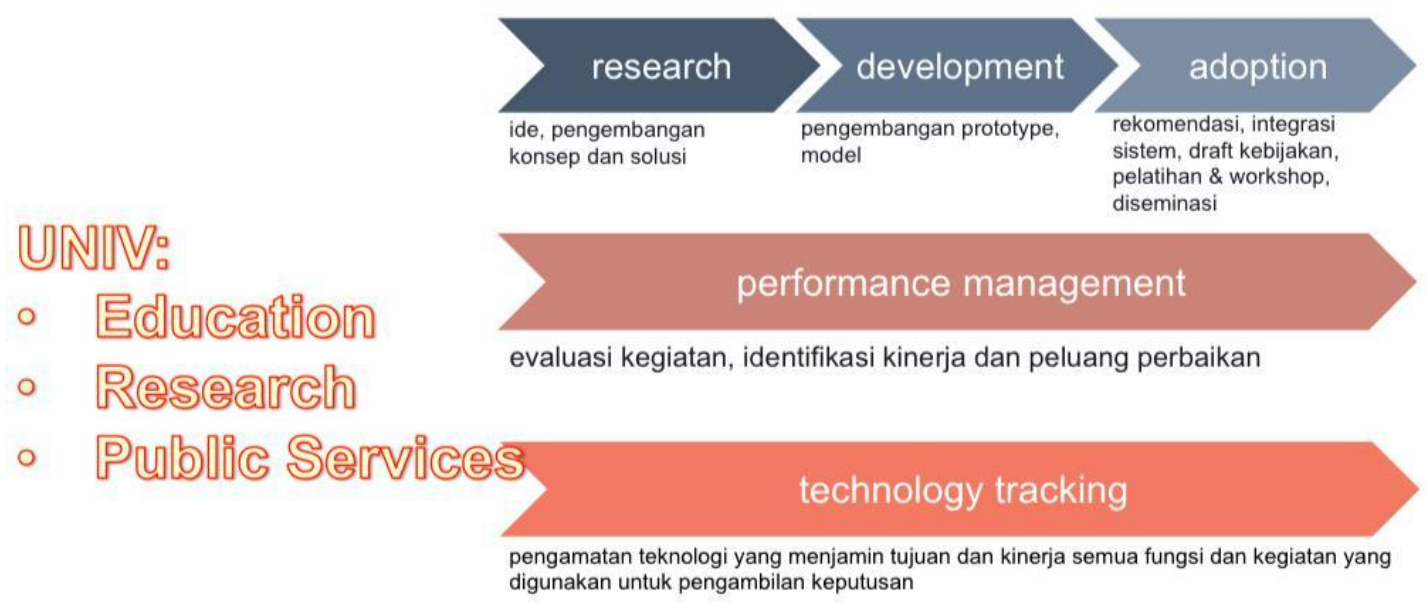

Gambar 3. LIFE CYCLE aktifitas SIEC-ITS

SIEC-ITS percaya, bahwa life cycle diatas baru akan dapat berjalan dengan baik apabila didukung dengan road-map yang memadai untuk kesinambungannya. Gambar dibawah ini, memberikan gambaran dan contoh roadmap dari salah satu sektor yang dikembangkan oleh SIEC-ITS. Setiap sektor akan mempunyai roadmapnya masing-masing, disesuaikan dengan kepakaran dan target akhir yang ingin dicapai. Dari gambar 4, Dari gambar terlihat, untuk menghasilkan kontribusi melalui smart-city dan intelligent solution, maka anggota team melakukan pendekatan yang disusun berdasar 3 Area Utama: A. Area Pengembangan Iptek, B. Area Teknologi Terapan dan C. Oleh SIEC-ITS ketiganya dianggap penting untuk dikembangkan secara bersamaan, karena memang dalam kenyaatannya semua harus sejalan.

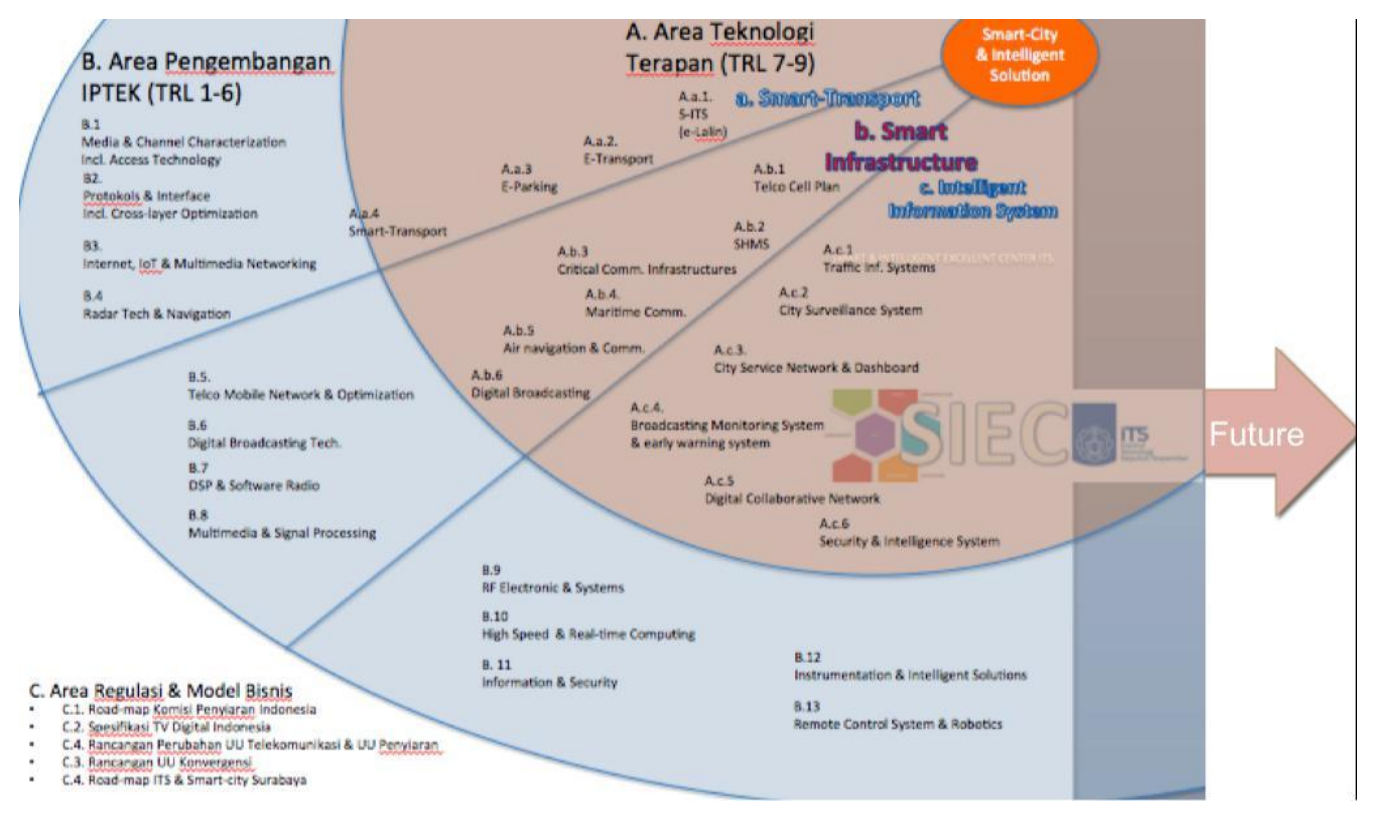

Gambar 4. Contoh Roadmap Aktifitas SIEC-ITS yang terkait dengan Sektor Keahlian Telekomunikasi Multimedia 


\section{INOVASI SIEC-ITS UNTUK MENDUKUNG SMART-CITY}

Sesuai dengan roadmap yang telah disusun, berikut ini adalah gambaran beberapa produk SIEC-ITC, atau kalau boleh disebut sebagai inovasi SIEC-ITS.

\subsection{Inovasi Bidang Smart-Transportation (SMART MOBILITY)}

\subsubsection{Manajemen Lalu-lintas S-ITS}

Salah satu yang sekarang menjadi andalan kota Surabaya, dan menjadi objek studi banding, adalah Sistem yang dikembangkan oleh team SIEC-ITS dari 2004 hingga sekarang. Sistem ini disebut dengan Surabaya's Intelligent Transportation System (S-ITS) yang merupakan alat pengendali lalu-lintas (cerdas) adaptif yang menggunakan CORE Optimization Engine SCATS System yang dikembangkan oleh Universitas Sydney di Australia. Dari 200 lebih kota yang menerapkan Engine ini, Surabaya merupakan satu-satunya kota yang berinovasi dengan mengembangkan interface dan protokolnya sendiri. Artinya, hanya core engine saja yang menggunakan produk import, karena mempertimbangkan aspek akuntabilitas produk dan jaminan kinerja. Sistem ini berhasil menekan laju kemacetan (V/C rasio) secara sangat signifikan. Berdasarkan sistem yang dikembangkan di Surabaya ini, maka di ITS juga dikembangkan sistem sejenis, tetapi dengan target untuk kota menengah dan kecil. Pemanfaatan sensor yang lebih sederhana, sistemm transmisi yang dioptimalkan dan server untuk kapasitas kecil, ITS (Team SIEC dari TMJ) berhasil membuat prototype yang berharga murah, dengan kualitas setara. Sistem ini sekarang dalam masa pengurusan patent, dengan pendanaan dari Kementerian Riset dan Dikti.

\subsubsection{Sistem Manajemen Armada dan Manajemen Revenu AMC}

Dengan memperhatikan kondisi transportasi modern, Surabaya merencanakan mempunyai sistem Angkutan Massal Cepat (AMC) yang mengkombinasikan antara Jaringan Feeder, Jaringan Trunk, Monortel dan Tram. Agar setiap unit dari armada AMC bisa dikendalikan dengan baik, maka dilakukan perancangan sistem manajemen armada dan sistem manajemen revenue. Sistem manajemen armada akan bertugas untuk mengatur armada, waktu antar keberangkatan, dan pengendalian armada yang lain, termasuk informasi penumpang (passenger information system). Dengan sistem ini, maka seluruh armada diharapkan dapat disinkronkan dan dioptimalkan.

Ada satu kunci penting dalam pelayanan transportasi kota, yaitu mengoptimalkan revenue agar masyarakat pengguna tidak terbebani tarif angkutan yang mahal dan kota dapat menerima PAD dari transportasi secara transparent dan akuntabel. Scenario menyatakan, bahwa kota membeli layanan dari operator (buy the service), untuk itu diperlukan sistem manajemen revenue yang terintegrasi dengan sistem manajemen armada. Dengan demikian memungkinkan masyarakat menikmati pembayaran optimal sesuai layanan yang digunakan, demikian juga dengan monitoring aktifitas armadanya. Sistem ini sudah siap diuji-cobakan dengan Server di Terminal Joyoboyo dan route uji MERR.

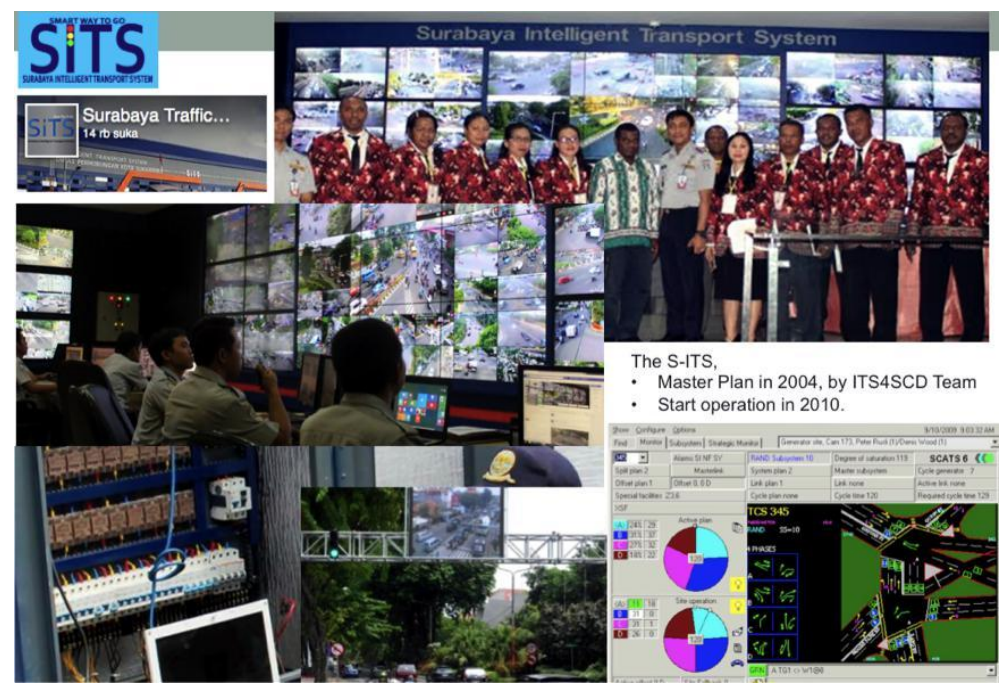

Gambar 5. Hasil Inovasi SIEC-ITS di Sistem Intelligent Transport (S-ITS)

\subsubsection{Gambar On-Board Unit (OBU)}

Kunci dari keberhasilan konsep di bab 4.1.2 terletak pada ketersediaan on-board unit (OBU) yang akan dipasang di kendaraan (bus, Tram atau Monorail). Obu ini berperan dalam dua hal:

- Untuk manajemen armada, OBU berfungsi berkomunikasi dengan halte dan server kendali dalam rangka mendeteksi lokasi kendaraan, jarak antar kendaraan, penyesuaian jadwal (scheduling) dan mengirim informasi penting ke passenger information system. 
- Untuk manajemen revenue, OBU berfungsi untuk mendeteksi identitas pengemudi, deteksi keberadaan penumpang melalui pemanfaatan RFID, menentukan jenis tariff dan nilai/ongkosnya, serta berkomunikasi dengan server manajemen revenue.

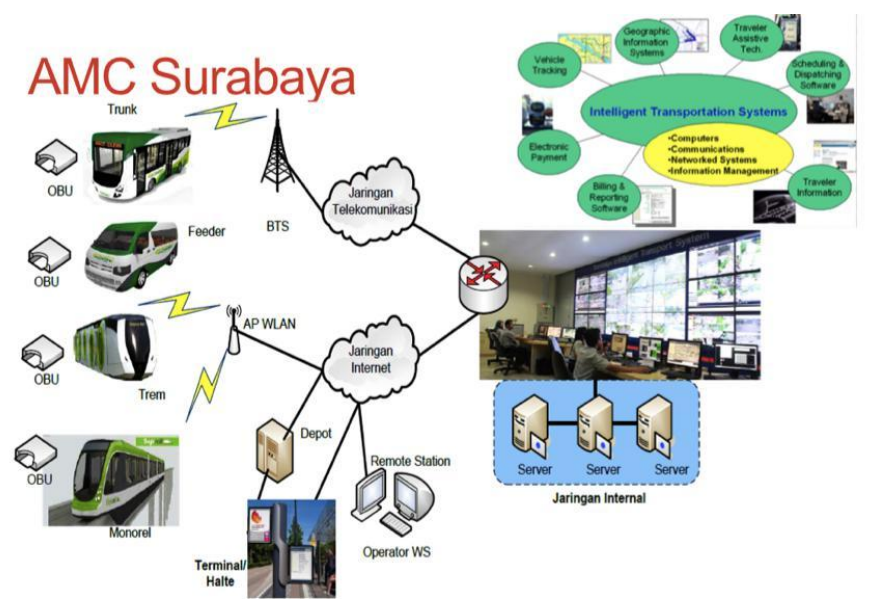

Gambar 5. Sistem Manajemen Armada dan Manajemen Revenue AMC Surabaya

\subsubsection{Manajemen Parkir dan e-Parkir}

Sangat difahami, bahwa parkir merupakan salah satu elemen penting dari manajemen lalu-lintas, satu bentuk pelayanan dan juga penghasil PAD. Untuk itulah SIEC-ITS mendapatkan kepercayaan untuk merencanakan, menyusun road-map dan sekaligus membuat inovasi sistem bagi Surabaya. Hasilnya adalah SIEC-ITS merekomendasikan sistem Zona yang nantinya progressive dan terintegrasi dalam sistem e-Parkir. Sistem e-Parkir melakukan intergasi tidak saja untuk parkir on-street, tetapi juga parkir off-street, termasuk Park \& Ride yang dibangun Surabaya dalam rangka mendukung AMC Surabaya.
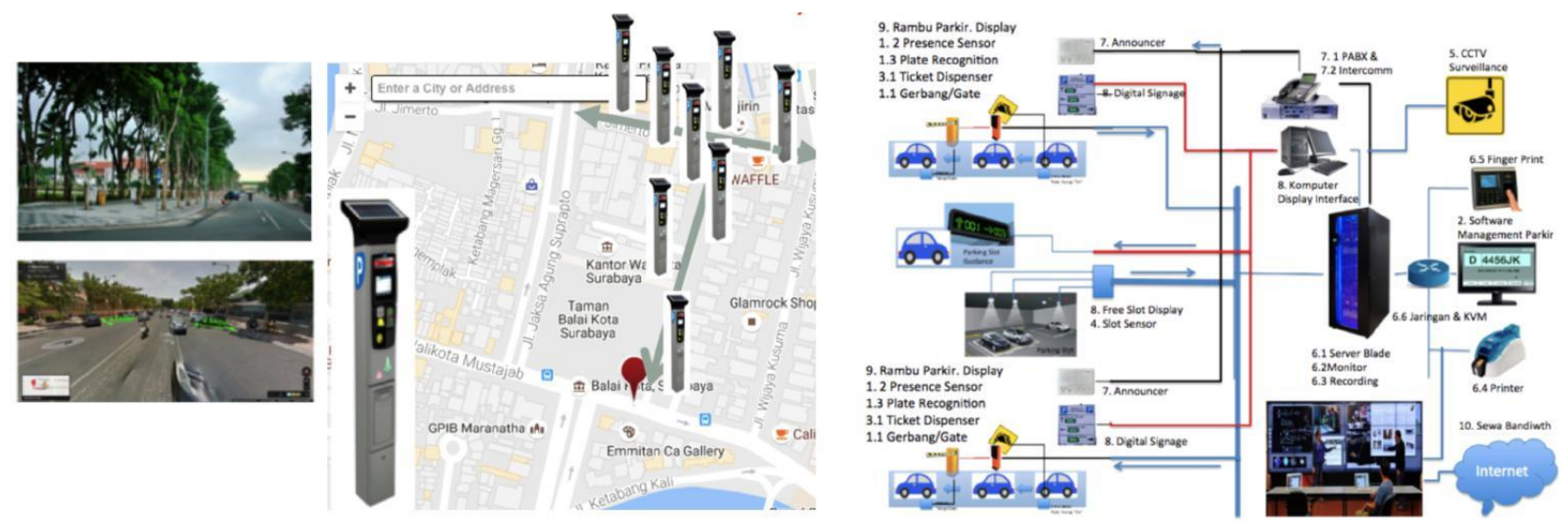

Gambar 6. Parkir Zona dan Sistem Manajemen Parkir (e-Parkir)

\subsection{5 e-Dishub}

Dengan semakin banyaknya aplikasi berbasis IT, maka dikembangkan sistem e-Dishub, sistem ini menggabungkan semua informasi IT dari seluruh UPTD dan unit yang dimiliki Dishub ke dalam sebuah platform yang terpadu. Untuk itu SIEC-ITS mengembangkan konsep interfacing dan pengembangan protocol multilayer agar semua aplikasi yang dikembangkan oleh pengembang yang berbeda dapat berkomunikasi dan diintegrasikan dalam satu platform.

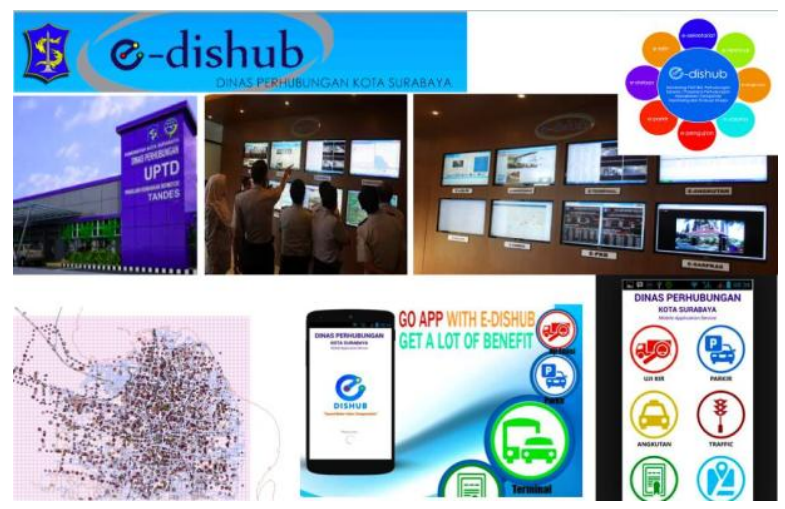

Gambar 7. Ilustrasi e-Dishub (IT Terintegrasi untuk Dinas Perhubungan) 


\subsubsection{SHMS (Structural Healt Monitoring System)}

Keselamatan transportasi diantaranya juga tergantung pada kualitas keamanan infrastruktur jalan dan juga jembatan. Dari sudut pandang tersebut SIEC-ITS dengan memberdayakan team ahli instrumentasi dan telekomunikasi (sensor, transmisi, akusisi data dan diseminasi) serta sipil konstruksi jembatan berperan dalam pengembangan sistem monitoring kesehatan struktur (SHMS) Jembatan. Intinya adalah penerapan TIK dengan memasang sensor pada titik-titik kritis jembatan dan menghubungkannya dengan sistem peringatan dini bencana. Setelah membantu melakukan asesmen sistem di Jembatan Suramadu, saat ini team sedang melakukan disain untuk Jembatan MUSI di Sumatera Selatan.

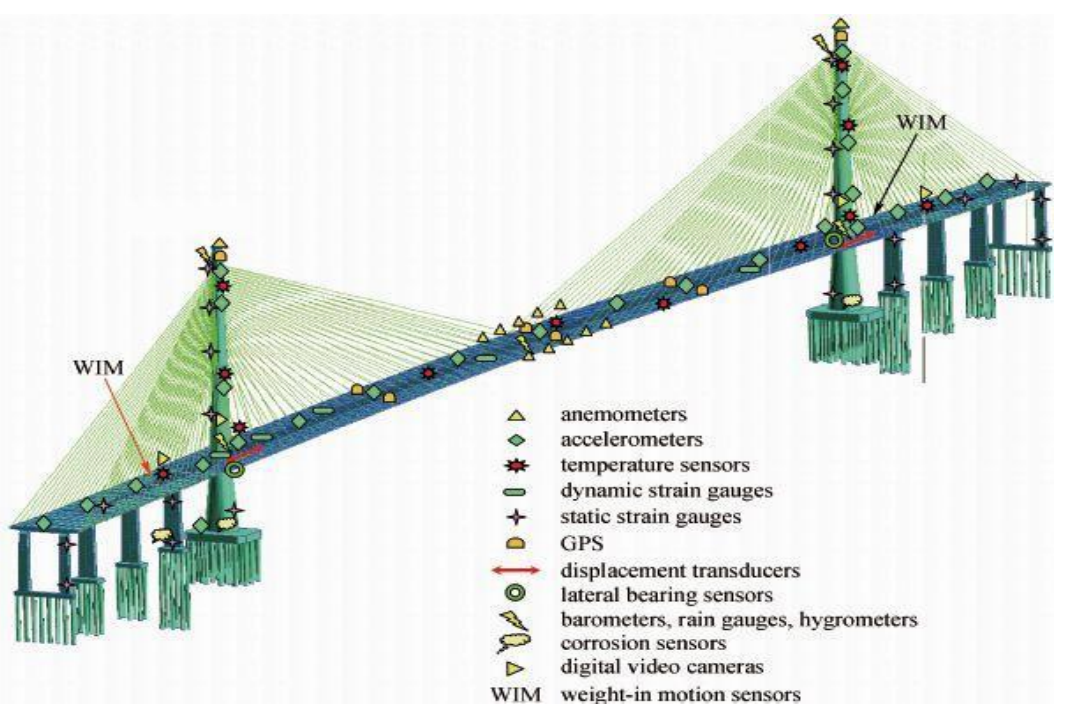

Gambar 8. Penerapan TIK untuk monitoring kesehatan jembatan

\subsection{Inovasi Bidang Komunikasi dan Informatika}

Sebenarnya, hampir semua infrastruktur TIK (kominfo) telah dapat dengan mudah didapatkan dan disediakan oleh vendor/ penyedia barang dan jasa. Pada banyak kasus nilai investasi TIK menjadi sangat besar apabila tidak dilakukan upaya inovasi, minimal optimalisasi. Melihat hal itu, SIEC-ITS bersama-sama team kominfo melakuka upaya bersama melalui aktifitas:

\subsubsection{Assessment dan Optimalisasi Jaringan}

Hasil asessmen dan optimalisasi jaringan, maka idle capacity dari jaringan pemkot dapat dikurangi dan beban biaya sewa bandwidth dapat diminimalkan. Selain itu kualitas (SLA) jaringan menjadi semakin baik.

\subsubsection{Cell planning \& propagation optimization}

Problem menara dan upaya melakukan program menara bersama, termasuk penggunaan MCP merupakan bidang yang membutuhkan pemahaman aspek propagasi dan telekomunikasi. Disinilah anggota Team SIEC-ITS bidang telekomunikasi berperan.

\subsubsection{Data-centre \& access control}

Semakin besar informasi yang disimpan dan diakses akan membutuhkan datacentre yang memadai. Kebutuhan optimal dan access control harus dihitung dan direncanakan secara cermat. Dalam hal ini team Jaringan dan Server yang berperan

\subsection{Inovasi di Bidang Penyiaran (Smart People)}

Masyarakat membutuhkan informasi yang baik dan sehat, dalam rangka membentuk smart-people. Maka SIEC-ITS melakukan berbagai inovasi yang disumbangkan kepada KPI/KPID yang diantaranya berupa 2 produk di bawah ini.

\subsubsection{Sistem Monitoring TV - KPID Jawa-Timur}

Yang secara mudah mendeteksi pelanggaran terhadap Pedoman Penyiaran TV.

\subsubsection{Sistem Monitoring Radio FM}

Yang secara mudah mendeteksi pelanggaran terhadap Pedoman Penyiaran radio RM.

\subsection{Kontribusi di Perencanaan dan Regulasi}

Di bidang regulasi dan perencanaan, SIEC-ITS berperan dan berkontribusi dalam penyusunan berbagai draft kebijakan, masterplan dan perundang-undangan. 


\subsubsection{Masterplan MP3EI Telematika Jawa-Timur}

Salah satu produk SIEC-ITS yang disumbangkan pada Bappeda Provinsi Jawa-Timur.

4.4.2 Roadmap Manajemen Lalu-Lintas ITS Surabaya; Masterplan e-Dishub dan Masterplan e-Parkir, Masterplan Jaringan Kominfo

Dokumen yang sangat diperlukan untuk acuan pembangunan dan investasi.

4.4.3 Narasumber Penyusunan Draft UU Konvergensi, Draft Perda, Draft Perwali dll.

Pengalaman meunjukkan, bahwa sebuah aturan teknis tidak cukup disusun oleh ahli hokum, tetapi membutuhkan juga ahli lain yang memahami proses bisnis, dan teknologi, selain aspek regulasi dan hokum.

\section{KESIMPULAN}

Dokumen ini memuat semua petunjuk yang diperlukan untuk menulis dan memasukkan makalah ke dalam Conference on Innovation and Industrial Application, dengan tema "Boosting Nation's Competitiveness through Research and Innovation".

SIEC-ITS mungkin masih merupakan embrio yang sangat kecil, tetapi mempunyai semangat yang sangat besar untuk berinovasi di bidang TIK, khususnya dalam konteks Smart-city dan Intelligent Solution. Dari kegiatan Penelitian yang terstruktur SIEC-ITS berharap dapat menemukan lebih banyak lagi inovasi tidak hanya di pilar-pilar tertentu dari Smartcity, tetapi di seluru aspek, dengan melibatkan peneliti dan laboratorium yang semakin besar.

\section{DAFTAR PUSTAKA}

Use the "Insert Citation" button to add citations to this document. 